\title{
Peningkatan Aktivitas dan Hasil Belajar Materi Sumber Daya Alam Melalui Model Pembelajaran Direct Instruction
}

\author{
Ngadilah ${ }^{1 *}$ \\ ${ }^{1} S D 2$ Gondangmanis, Kudus, Indonesia
}

\author{
A R T I C L E I N F O \\ Article history: \\ Received 19 February \\ 2021 \\ Received in revised form \\ 30 March 2021 \\ Accepted 10 April 2021 \\ Available online 11 May \\ 2021 \\ Kata Kunci: \\ Aktivitas, Hasil Belajar, \\ Direct Instruction. \\ Keywords: \\ Activities, Learning \\ Outcomes, Direct \\ Instruction.
}

\begin{abstract}
A B S T R A K
Kurang aktifnya siswa didalam pembelajaran dibuktikan dengan rendahnya hasil belajar siswa mengenai materi IPS, hal ini dikarenakan penggunaan model pembelajaran yang kurang efektif, sehingga dibutuhkan model pembelajaran yang efektif untuk meningkatkan aktivitas dan hasil belajar siswa. Penelitian bertujuan untuk menganalisis aktivitas dan hasil belajar IPS materi sumber daya alam melalui model pembelajaran Direct Instruction pada siswa kelas IV. Penelitian yang dilakukan ini merupakan penelitian tindakan kelas (PTK). Subjek penelitian ini adalah aktivitas dan hasil belajar siswa kelas IV pada mata pelajaran IPS materi sumber daya alam yang berjumlah 21 siswa. Teknik pengumpulan data yang digunakan adalah memberikan instrumen tes hasil belajar IPS materi sumber daya alam kepada siswa. Teknik analisis data pada penelitian ini menggunakan teknik analisis data statistik kuantitatif. Hasil penelitian ini menunjukkan bahwa aktivitas belajar siswa pada siklus I presentase sebesar $73,45 \%$, pada siklus II sebesar $90,35 \%$, dan presentase ketuntasan belajar mencapai $85,71 \%$. Simpulan penelitian ini adalah penerapan model pembelajaran Direct Instruction
\end{abstract} dapat meningkatkan aktivitas dan hasil belajar siswa pada mata pelajaran IPS materi sumber daya alam. Implikasi penelitian ini adalah meningkatkan pengetahuan faktual yang diajarkan secara tahap demi tahap dengan tujuan untuk membantu siswa menguasai pengetahuan prosedural yang dibutuhkan untuk melakukan berbagai keterampilan kompleks.

\begin{abstract}
A B S T R A K
The inactivity of students in learning is evidenced by the low student learning outcomes regarding social studies material, this is due to the use of ineffective learning models, so an effective learning model is needed to increase student activity and learning outcomes. The research aims to analyze the activities and social studies learning outcomes of natural resources through the Direct Instruction learning model for grade IV students. This research is a classroom action research (PTK). The subjects of this study were the activities and learning outcomes of the fourth-grade students in the social studies subject on natural resources, totaling 21 students. The data collection technique used was to provide students with a test instrument for social studies learning outcomes on natural resources. The data analysis technique in this study used quantitative statistical data analysis techniques. The results of this study indicate that the percentage of student learning activities in the first cycle is $73.45 \%$, in the second cycle it is $90.35 \%$, and the percentage of learning completeness reaches $85.71 \%$. The conclusion of this research is that the application of the Direct Instruction learning model can increase the activity and learning outcomes of students in social studies subjects in natural resources material. The implication of this research is to increase factual knowledge which is taught step by step with the aim of helping students master the procedural knowledge needed to perform various complex skills.
\end{abstract}




\section{Pendahuluan}

Kemajuan suatu bangsa di masa yang akan datang tergantung dari mutu pendidikan generasi muda saat ini. Tujuan pendidikan yang harus dicapai pada hakekatnya merupakan bentuk-bentuk atau pola tingkah laku yang harus dikuasai oleh peserta didik yang meliputi pengetahuan, sikap dan keterampilan. Untuk mencapai tujuan pendidikan tentunya harus dimulai dengan pengadaan tenaga kependidikan sampai pada usaha peningkatan mutu tenaga kependidikan atau pengajar dalam proses belajar mengajar. Tenaga kependidikan diharuskan mampu mengembangkan model pembelajaran yang tepat. Pendekatan pembelajaran yang digunakan dalam proses belajar mengajar dapat dianggap sebagai suatu jalan atau cara yang teratur untuk meciptakan sistem pendidikan yang baik (Kurniasari, 2017; Raditya \& Iskandar, 2020; Sutrisno, 2015).

Sistem pendidikan yang baik akan melahirkan generasi bangsa yang cerdas dan baik pula. Generasi bangsa yang cerdas ialah modal awal bagi suatu bangsa dalam melakukan pembangunan ke arah yang lebih baik dalam usaha mencapai pembangunan nasional (Aprilia, 2018; Mulyadin, 2016; Raditya \& Iskandar, 2020). Pembangunan yang dilakukan oleh suatu bangsa menandakan bahwa bangsa tersebut merupakan bangsa yang bermartabat karena selalu melakukan peningkatan kualitas dan beradaptasi dengan peradaban zaman. Dari pernyataan tersebut tersirat pesan bahwa pendidikan perlu mendapatkan perhatian yang serius.

Peran pendidikan sangat dibutuhkan dalam rangka mempersiapkan Sumber Daya Manusia (SDM) yang berkualitas, di antaranya menyelenggarakan sistem pembelajaran yang mengacu pada mutu hasil pendidikan yang tepat guna. Untuk itu, perlu adanya sistem kurikulum yang tepat, pelaksanaan pendidikan yang berkompeten dan guru yang memiliki semangat untuk maju dengan menggunakan media, metode, pendekatan mengajar, sarana pembelajaran yang sesuai dengan tujuan dan materi yang diajarkan, sehingga siswa lebih memahami dan mengerti apa yang dimaksudkan, untuk mencapai tujuan yang dikehendaki (Krissandi \& Rusmawan, 2015; Sufanti et al., 2017; Wahyudin, 2018).

Tujuan pendidikan nasional ini akan tercapai apabila semua pihak ikut serta mendukung kemajuan pendidikan itu, baik oleh pemerintah, guru sebagai pendidik maupun masyarakat. Usaha yang dilakukan pemerintah dalam meningkatkan mutu pendidikan yaitu dengan mengeluarkan berbagai kebijakan dan mengambil langkah-langkah perbaikan seperti perbaikan kurikulum, pemerataan tenaga pendidikan, sertifikasi guru, pemberian dana bantuan operasional sekolah serta penerapan ide-ide baru untuk peningkatan mutu pendidikan termasuk mutu guru (Astawa et al., 2020; Khofiatun et al., 2016; Mangesa \& Andayani, 2015).

Guru memberikan peranan penting didalam pendidikan terutama didalam kegiatan belajar mengajar, agar kegiatan belajar mengajar berhasil maka guru dituntut untuk menguasai dan memahami berbagai keterampilan yang dapat mendukung efektivitas dan efesiensi kegiatan belajar mengajar. Guru adalah salah satu komponen pendidikan yang sangat berperan dalam usaha pembentukan sumber daya manusia yang potensial di bidang pembangunan. Oleh karena itu, guru merupakan salah satu unsur kependidikan harus berperan serta secara aktif dalam menempatkan kedudukannya sebagai tenaga profesional. Pada diri guru terletak tanggung jawab untuk membawa siswa pada suatu kedewasaan atau taraf kematangan tertentu dengan mengajarkan pendidikan karakter (Amran et al., 2019; Surya, 2017; Taunu \& Iriani, 2019).

Pendidikan karakter adalah pendidikan yang menekankan pada perilaku baik yang dilakukan secara berkesinambungan menjadi sebuah pembiasaan. Pendidikan karakter membentuk siswa memiliki karakter unggulan yang berguna sebagai bekal dalam mengarungi kehidupannya. Pendidikan karakter yang dilakukan di sekolah senantiasa berintegrasi dengan seluruh mata pelajaran dan setiap kegiatan pembelajaran. Karakter yang dibentuk diharapkan dapat terus berkembang sehingga akhirnya membudaya (Amran, Jasin et al., 2019; Ekayani et al., 2019; Ridwan \& Mas'odi, 2017).

Pembelajaran didesain untuk membelajarkan siswa, artinya siswa ditempatkan sebagai subjek belajar. Dengan kata lain, pembelajaran lebih berorientasi pada aktivitas siswa untuk memperoleh hasil belajar berupa perpaduan antara aspek kognitif, afektif, dan psikomotor secara proposional. Keaktifan siswa ada yang secara langsung dapat diamati dan ada yang tidak dapat diamamti secara langsung, seperti mengerjakan tugas, berdiskusi, dan mengumpulkan data. Kadar keaktifan siswa tidak hanya ditentukan oleh aktivitas fisik semata, tetapi juga oleh aktivitas nonfisik seperti mental, intelektual, dan emosional (Risvanelli, 2017; Widodo, 2014; Yoserizal \& Rahmi, 2019). Oleh sebab itu, aktif atau tidaknya siswa dalam belajar hanya siswa sendiri yang mengetahui secara pasti.

Berdasarkan data awal hasil tes formatif pembelajaran IPS materi sumber daya alam dapat diketahui bahwa siswa belum mampu menyerap dan memahami materi secara maksimal. Hal tersebut 
dibuktikan dengan hasil tes yang dilakukan guru sebagai evaluasi dengan ketetapan nilai KKM sebesar 67 untuk mata pelajaran IPS, terdapat $11(47,62 \%)$ dari 21 siswa, belum memenuhi KKM. Hasil analisis pembelajaran yang dilakukan guru kelas IV, bahwa hal demikian terjadi karena siswa sulit diajak ikut aktif dalam pembelajaran. Siswa merasa bosan dan kurang tertarik dengan pembelajaran yang telah disampaikan serta pemahaman siswa terhadap materi menjadi kurang optimal sehingga berpengaruh terhadap hasil belajar siswa. Salah satu upaya yang dapat dilakukan untuk meningkatkan kualitas pembelajaran yaitu menerapkan model pembelajaran yang sesuai dengan materi dan kondisi lingkungan sekitar, yaitu model pembelajaran Direct Instruction.

Model pembelajaran langsung adalah program yang paling efektif untuk mengukur pencapaian keahlian dasar, keahlian dalam memahami suatu materi dan konsep diri sendiri. Model ini sangat ditentukan oleh pendidik, artinya pendidik berperan penting dan dominan dalam proses pembelajaran (Saputro, 2016; Usman, 2014; Wintarti, 2017). Penyebutan ini mengacu pada gaya mengajar di mana pendidik terlibat aktif dalam mengusung isi pelajaran kepada peserta didik dan mengajarkannya kepada seluruh peserta didik dalam kelas.

Model Direct Instruction merupakan model pembelajaran yang dimaksudkan untuk membantu siswa mempelajari berbagai keterampilan dan pengetahuan dasar yang diajarkan secara tahap demi tahap (Haryanti et al., 2018; Maarif et al., 2020; Rais \& Suswanto, 2017). Pengajaran langsung dirancang untuk meningkatkan penguasaan berbagai keterampilan pengetahuan deklaratif dan pengetahuan prosedural yang dapat diajarkan secara bertahap.

Pembelajaran dengan menerapkan model pembelajaran Direct Instruction merupakan pembelajaran yang menekankan penyampaian materi dilakukan secara verbal oleh guru kepada para peserta didik. (Damanik \& Bukit, 2013; Falentina, 2017; Hastari et al., 2020), menyatakan menamakan model ekspositori ini dengan istilah Direct Instruction, model ini lebih menekankan pada proses bertutur maka sering disebut juga dengan istilah chalk and talk (ceramah dan mencatat). Kelebihan dari Model Direct Instruction pembelajarannya dirancang secara spesifik untuk meningkatkan pengetahuan faktual yang diajarkan secara tahap demi tahap dengan tujuan untuk membantu siswa menguasai pengetahuan prosedural yang dibutuhkan untuk melakukan berbagai keterampilan kompleks (Jamilah et al., 2017; Kusumawati, 2016; Safputri et al., 2016).

Penelitian ini didukung dengan penelitian terdhulu yang relevan dengan penelitian ini, meliputi: pertama penelitian yang dilakukan oleh (Jamilah et al., 2017), yang mendapatkan hasil penelitian yaitu kemampuan pembuktian matematis terbukti dapat dipengaruhi melalui penerapan model penemuan terbimbing dan pembelajaran langsung (Direct Instruction). Kedua, penelitian yang dilakukan oleh (Haryanti et al., 2018), yang mendapatkan hasil penelitian yaitu peningkatan hasil belajar siswa terbukti dapat dipengaruhi melalui model direct instruction berbantuan media bagan garis waktu. Ketiga, penelitian yang dilakukan oleh (Wintarti, 2017), yang mendapatkan hasil penelitian yaitu peningkatan prestasi belajar IPS terbukti dapat dipengaruhi melalui model pembelajaran Direct Instruction dengan media visual berbantuan komputer.

Tujuan penelitian ini adalah untuk menganalisis aktivitas dan hasil belajar ilmu pengetahuan sosial materi sumber daya alam pada siswa kelas IV SD 2 Gondangmanis semester I tahun pelajaran $2017 / 2018$.

\section{Metode}

Penelitian yang dilakukan ini merupakan penelitian tindakan kelas (PTK) yang terdiri dari dua siklus. Setiap siklus terdiri dari empat tahap yaitu perencanaan, tindakan, pengamatan, dan analisis atau refleksi (Fitri et al., 2020; N Rerung et al., 2017; Nensy Rerung et al., 2017). Dalam perencanaan ini meliputi identifikasi masalah, menganalisis penyebab masalah dan menetapkan tindakan pemecahannya. Langkah selanjutnya membuat skenario pembelajaran dengan menyusun RPP yang terdapat proses pembelajaran model Direct Instruction. Pelaksanaan tindakan (acting) sesuai skenario pembelajaran yang direncanakan. Pada tiap-tiap siklus yaitu menerapkan pembelajaran model Direct Instruction, pada siklus II merupakan hasil pengembangan atas refleksi hasil siklus I. Subjek penelitian ini adalah aktivitas dan hasil belajar siswa kelas IV pada mata pelajaran ilmu pengetahuan sosial materi sumber daya alam yang berjumlah 21 siswa, siswa laki-laki sebanyak 9 siswa dan 12 siswa perempuan. Teknik pengumpulan data yang digunakan pada penelitian ini adalah memberikan instrumen tes hasil belajar mata pelajaran ilmu pengetahuan sosial (IPS) materi sumber daya alam kepada siswa kelas IV. Metode tes digunakan untuk memperoleh data tentang tingkat kemampuan penguasaan materi pembelajaran sebelum dan sesudah pembelajaran. Teknik analisis data pada penelitian ini menggunakan teknik analisis data statistik kuantitatif. Teknik analisis ini digunakan untuk menganalisis aktivitas dan hasil belajar siswa kelas IV pada mata pelajaran ilmu pengetahuan sosial materi sumber daya alam. 


\section{Hasil dan Pembahasan}

Hasil penelitian tindakan kelas melalui model pembelajaran Direct Instruction yang diperoleh dari hasil tes dan nontes yang terlaksana dalam dua siklus. Setiap siklusnya dua kali pertemuan yang dapat meningkatkan kualitas pembelajaran yang berupa aktivitas dan hasil belajar siswa kelas IV SD 2 Gondangmanis Kudus. Pada pelaksanaan kegiatan pembelajaran prasiklus, nilai tuntas belajar secara klasikal hasil belajar IPS kelas IV adalah 47,62\%, di bawah standar Kriteria Ketuntasan Minimal (KKM) yaitu taraf serap pencapaian target 67 secara individual dan 80\%. Kecenderungan perolehan nilai kriteria ketuntasan minimal kurang memacu peneliti untuk mengadakan tindakan penelitian serta merumuskan faktor-faktor penyebabnya untuk mencari solusi terbaik dengan hasil optimal.

Berdasarkan hasil tes formatif pembelajaran IPS pada siklus I melalui model pembelajaran Direct Instruction pada siswa kelas IV SD 2 Gondangmanis Kudus, diperoleh data hasil belajar siswa siklus I dapat dilihat pada Tabel 1.

Tabel 1. Hasil Belajar Siswa Siklus I

\begin{tabular}{ccccc}
\hline Rentang Nilai & Kategori & Frek & Nilai & Persen \\
\hline $89-100$ & SB & 3 & 280 & $14,29 \%$ \\
$78-88$ & Baik & 4 & 325 & $19,05 \%$ \\
$67-77$ & Cukup & 8 & 565 & $38,09 \%$ \\
$\leq 67$ & Kurang & 6 & 310 & $28,57 \%$ \\
Jumlah & & 21 & 1480 & $100 \%$ \\
Rata2 & & & 70,48 & $71,43 \%$ \\
Tuntas & $\geq 67$ & 15 & & $28,57 \%$ \\
Belum tuntas & $\leq 67$ & 6 & & \\
\hline
\end{tabular}

Berdasarkan Tabel 1 diperoleh data bahwa ada 15 siswa atau sebesar 71,43\% mengalami ketuntasan belajar secara klasikal, sedangkan siswa yang mendapatkan nilai di bawah KKM 67 secara klasikal ada 6 siswa atau sebesar 28,57\%. Dari tabel di atas dapat diketahui bahwa nilai rata-rata hasil belajar siswa pada awal sebelum pelaksanaan siklus sebesar 61,43 dengan nilai terendah 40, nilai tertinggi 90, persentase ketuntasan sebesar $47,62 \%$ dan $52,38 \%$ siswa belum memenuh ketuntasan minimal yang ditetapkan yaitu 67. Setelah dilaksanakan siklus I nilai rata-rata menjadi 70,48 dengan nilai terendah 50, nilai tertinggi 100 . Persentase ketuntasan 71,43\% dan 28,57\% siswa belum memperoleh nilai ketuntasan minimal. Presentase hasil belajar siklus I dapat dilihat pada Gambar 1.

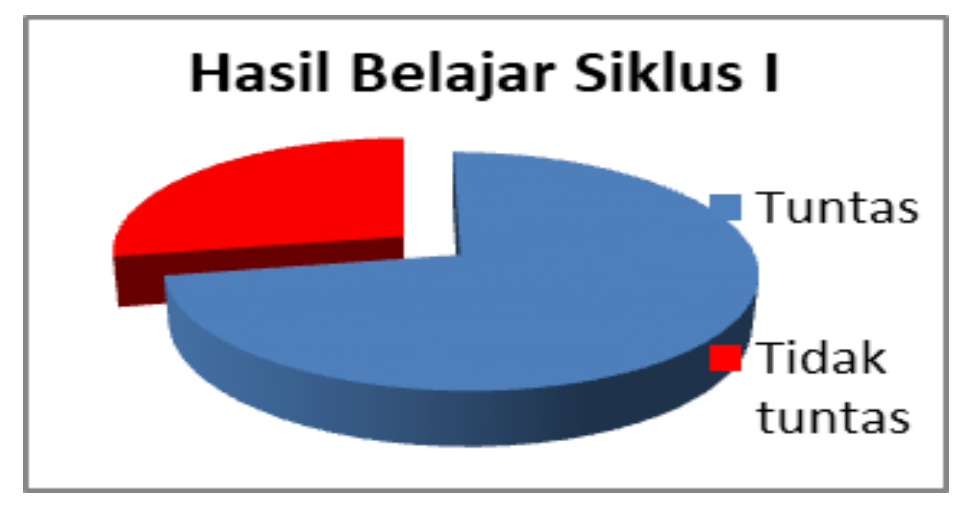

Gambar 1. Tindakan siklus I

Pada pembelajaran sebelum tindakan penelitian, peneliti hanya mengandalkan metode konvensional yaitu ceramah, tanya jawab, dan pemberian tugas, sehingga hasil yang dicapai adalah siswa yang memperoleh nilai $67 \mathrm{ke}$ atas hanya 10 dari 21 siswa atau 47,62\%. Dengan nilai terendah 40, nilai tertinggi 90 dan nilai rata-rata 61,43. Berdasarkan hasil tersebut peneliti bermaksud untuk meningkatkan aktivitas dan hasil belajar siswa tentang sumber daya alam dengan melaksanakan model pembelajaran Direct Instruction.

Berdasarkan pelaksanaan tindakan pada siklus I, diperoleh data hasil belajar siswa kelas IV SD 2 Gondangmanis Kudus dengan nilai rata-rata ketuntasan klasikal 71,43\%. Hasil tersebut menunjukkan peningkatan sebesar 23,81\% jika dibandingkan dengan data awal dengan ketuntasan klasikal sebesar 
47,62\%. Perolehan hasil belajar siswa menujukkan bahwa dalam tes formatif nilai rata-rata kelas sebesar 70,48 dan presentase ketuntasan belajar mencapai 71,43\%. Nilai tertinggi 100 dan nilai terendah 50. Nilai ketuntasan minimal (KKM) 67. Perolehan hasil belajar belum memenuhi kriteria ketuntasan belajar klasikal yakni 80\%. Dari 21 siswa ada 15 siswa yang memenuhi nilai KKM dan masih ada 6 siswa yang mendapat nilai di bawah KKM. Dengan demikian masih ada 6 siswa yang belum mencapai KKM dan belum mencapai ketuntasan belajar klasikal.

Pada pembelajaran siklus II, penerapan model pembelajaran Direct Instruction pada materi sumber daya alam mengalami peningkatan yang cukup baik. Hal tersebut dapat diketahui dari perolehan tes yang mengukur hasil belajar siswa menujukkan bahwa dalam tes formatif nilai rata-rata kelas sebesar 78,57 dan presentase ketuntasan belajar klasikalnya mencapai 85,71\%. Nilai ketuntasan minimal (KKM) yang telah ditentukan yaitu 67, sedangkan kriteria ketuntasan belajar klasikal yakni $80 \%$. Hal ini menunjukkan keberhasilan pembelajaran pada siklus II. Secara visual rekapitulasi hasil belajar siswa pada prasiklus, siklus I dan siklus II dapat dilihat pada Gambar 2.

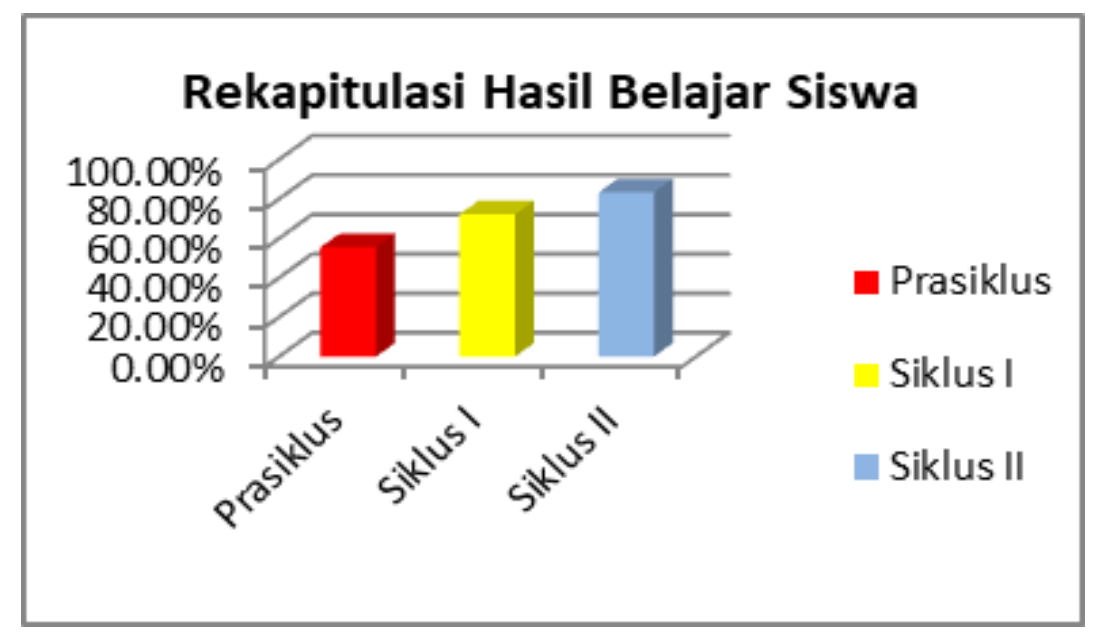

Gambar 2. Rekapitulasi hasil belajar siswa pada siklus I dan siklus II

Pembelajaran IPS materi sumber daya alam menggunakan model Direct Instruction juga dapat meningkatkan aktivitas siswa dari siklus I ke siklus II selama pelaksanaan tindakan pembelajaran. Hasil observasi aktivitas siswa dalam mengikuti pembelajaran IPS materi sumber daya alam melalui model Direct Instruction pada siklus I memperoleh skor 20,8 atau sebesar 73,45\% dengan kategori tinggi. Pada siklus II memperoleh jumlah skor 25,4 atau sebesar 90,35\% dengan kategori sangat tinggi. rekapitulasi aktivitas belajar siswa pada siklus I dan siklus II dapat dilihat pada Gambar 3.

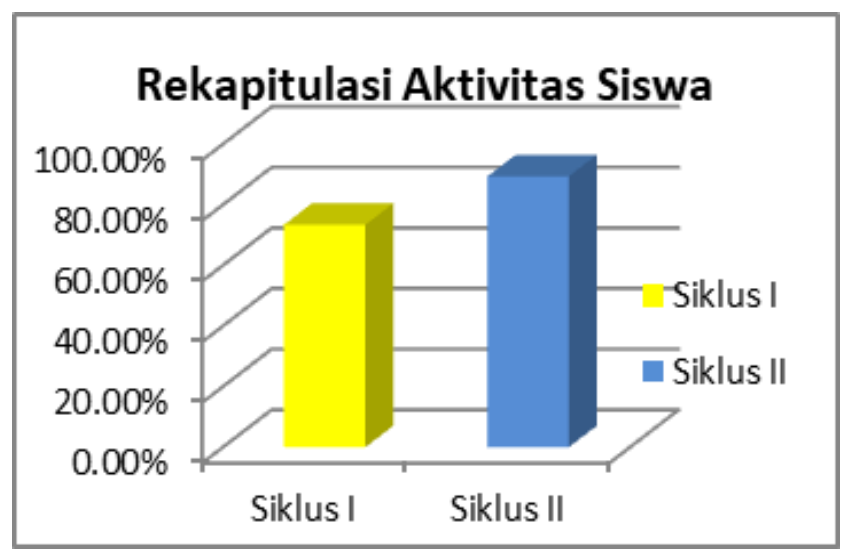

Gambar 3. Rekapitulasi aktivitas belajar siswa pada siklus I dan siklus II.

Berdasarkan Gambar 3, dapat disimpulkan bahwa penerapan model Direct Instruction dapat meningkatkan aktivitas dan hasil belajar IPS materi sumber daya alam pada siswa kelas IV SD 2 Gondangmanis Semester I Tahun Pelajaran 2017/2018. 
Model pembelajaran langsung adalah program yang paling efektif untuk mengukur pencapaian keahlian dasar, keahlian dalam memahami suatu materi dan konsep diri sendiri. Model ini sangat ditentukan oleh pendidik, artinya pendidik berperan penting dan dominan dalam proses pembelajaran (Saputro, 2016; Usman, 2014; Wintarti, 2017). Penyebutan ini mengacu pada gaya mengajar di mana pendidik terlibat aktif dalam mengusung isi pelajaran kepada peserta didik dan mengajarkannya kepada seluruh peserta didik dalam kelas. Model Direct Instruction merupakan model pembelajaran yang dimaksudkan untuk membantu siswa mempelajari berbagai keterampilan dan pengetahuan dasar yang diajarkan secara tahap demi tahap (Haryanti et al., 2018; Maarif et al., 2020; Rais \& Suswanto, 2017). Pengajaran langsung dirancang untuk meningkatkan penguasaan berbagai keterampilan pengetahuan deklaratif dan pengetahuan prosedural yang dapat diajarkan secara bertahap. Pembelajaran dengan menerapkan model pembelajaran Direct Instruction merupakan pembelajaran yang menekankan penyampaian materi dilakukan secara verbal oleh guru kepada para peserta didik. (Damanik \& Bukit, 2013; Falentina, 2017; Hastari et al., 2020), menyatakan menamakan model ekspositori ini dengan istilah Direct Instruction, model ini lebih menekankan pada proses bertutur maka sering disebut juga dengan istilah chalk and talk (ceramah dan mencatat). Kelebihan dari Model Direct Instruction pembelajarannya dirancang secara spesifik untuk meningkatkan pengetahuan faktual yang diajarkan secara tahap demi tahap dengan tujuan untuk membantu siswa menguasai pengetahuan prosedural yang dibutuhkan untuk melakukan berbagai keterampilan kompleks (Jamilah et al., 2017; Kusumawati, 2016; Safputri et al., 2016).

Penelitian ini didukung dengan penelitian terdhulu yang relevan dengan penelitian ini, meliputi: pertama penelitian yang dilakukan oleh (Jamilah et al., 2017), yang mendapatkan hasil penelitian yaitu kemampuan pembuktian matematis terbukti dapat dipengaruhi melalui penerapan model penemuan terbimbing dan pembelajaran langsung (Direct Instruction). Kedua, penelitian yang dilakukan oleh (Haryanti et al., 2018), yang mendapatkan hasil penelitian yaitu peningkatan hasil belajar siswa terbukti dapat dipengaruhi melalui model direct instruction berbantuan media bagan garis waktu. Ketiga, penelitian yang dilakukan oleh (Wintarti, 2017), yang mendapatkan hasil penelitian yaitu peningkatan prestasi belajar IPS terbukti dapat dipengaruhi melalui model pembelajaran Direct Instruction dengan media visual berbantuan komputer.

Implikasi penelitian tindakan kelas tentang penerapan model Direct Instruction ini adalah meningkatkan pengetahuan faktual yang diajarkan secara tahap demi tahap dengan tujuan untuk membantu siswa menguasai pengetahuan prosedural yang dibutuhkan untuk melakukan berbagai keterampilan kompleks.

\section{Simpulan}

Berdasarkan hasil penelitian yang telah dilakukan dapat disimpulkan bahwa penerapan model Direct Instruction dapat meningkatkan aktivitas dan hasil belajar IPS materi sumber daya alam pada siswa kelas IV SD 2 Gondangmanis Semester I Tahun Pelajaran 2017/2018. Implikasi penelitian ini adalah meningkatkan pengetahuan faktual yang diajarkan secara tahap demi tahap dengan tujuan untuk membantu siswa menguasai pengetahuan prosedural yang dibutuhkan untuk melakukan berbagai keterampilan kompleks.

\section{Daftar Rujukan}

Amran, Jasin, I., Perkasa, M., Satriawan, M., \& Irwansyah, M. (2019). Model Pembelajaran Berbasis Nilai Pendidikan Karakter Untuk Generasi Indonesia Abad 21. Lentera Pendidikan, 22(2), 233-242. https://doi.org/10.24252/lp.2019v22n2i5

Amran, Jasin, I., Perkasa, M., Satriawan, M., \& Irwansyah, M. (2019). Model Pembelajaran Berbasis Nilai Pendidikan Karakter Untuk Generasi Indonesia Abad 21. Lentera Pendidikan, 22(2), 233-242. https://doi.org/10.24252/lp.2019v22n2i5

Aprilia, L. A. (2018). Meningkatkan Hasil Belajar Ppkn Melalui Model Pembelajaran Numbered Heads Together (Nht) Berbasis Kurikulum 2013. Wacana Akademika: Majalah Ilmiah Kependidikan, 2(1). https://doi.org/10.30738/wa.v2i1.2530

Astawa, I. W. W., Putra, M., \& Abadi, I. B. G. S. (2020). Pembelajaran PPKn dengan Model VCT Bermuatan Nilai Karakter Meningkatkan Kompetensi Pengetahuan Siswa. Jurnal Pedagogi Dan Pembelajaran, 3(2), 199-210. https://doi.org/10.23887/jp2.v3i2.25677

Damanik, D. P., \& Bukit, N. (2013). Analyze Critical Thinking Skills And Scientific Attitude In Physics 
Learning Used Inquiry Training And Direct Instruction Learning Model. Jurnal Pendidikan Fisika, 2(1), 16-24. https://doi.org/10.22611/jpf.v2i1.4333

Ekayani, N. W., Antara, P. A., \& Suranata, K. (2019). Pengaruh Model Pembelajaran Value Clarification Technique (VCT) Terhadap Karakter. Mimbar PGSD Undiksha, 6(3), 163-172. https://doi.org/10.23887/jjpgsd.v7i3.19386

Falentina, U. (2017). Memanfaatkan Metode Kerja Kelompok dalam Model Direct Instruction Untuk Mengoptimalkan Peningkatan Prestasi Belajar Matematika Siswa Kelas 8 Semester I Tahun Pelajaran 2015/2016 DI SMPN 8 Bintan. Jurnal Ilmiah Pendidikan Matematika, 5(2), 131-137. https://doi.org/10.25273/jipm.v5i2.1176

Fitri, M., Yuanita, P., \& Maimunah, M. (2020). Pengembangan Perangkat Pembelajaran Matematika Terintegrasi Keterampilan Abad 21 Melalui Penerapan Model Problem Based Learning (PBL). Jurnal Gantang, 5(1), 77-85. https://doi.org/10.31629/jg.v5i1.1609

Haryanti, Y. D., Febriyanto, B., \& Nuraisyah, I. F. (2018). Upaya Meningkatkan Hasil Belajar Siswa Melalui Model Direct Instruction Berbantuan Media Bagan Garis Waktu. Jurnal Cakrawala Pendas, 4(2), 23-41. https://doi.org/10.31949/jcp.v4i2.1074

Hastari, R. C., Zuhroh, Y. E., Purwanto, P., \& Susiana, A. (2020). Kesalahan Mahasiswa dalam Menyelesaikan Soal Matematika pada Penerapan Model Pembelajaran Langsung (Direct Instruction). Jurnal Tadris Matematika, 3(1), 21-30. https://doi.org/10.21274/jtm.2020.3.1.21-30

Jamilah, J., Hartono, H., \& Susiaty, U. D. (2017). Komparasi Model Penemuan Terbimbing Dan Pembelajaran Langsung Terhadap Kemampuan Pembuktian Matematis. Jurnal Aksioma, 6(2), 218-224. https://doi.org/10.24127/ajpm.v6i2.962

Khofiatun, Akbar, S., \& Ramli, M. (2016). Peran Kompetensi Pedagogik Guru Dalam Pembelajaran Tematik Di Sekolah Dasar. Jurnal Pendidikan, 1(5), 984-988. https://doi.org/10.17977/jp.v1i5.6336

Krissandi, A. D. S., \& Rusmawan, R. (2015). Kendala Guru Sekolah Dasar Dalam Implementasi Kurikulum 2013. Jurnal Cakrawala Pendidikan, 3(3), 457-467. https://doi.org/10.21831/cp.v3i3.7409

Kurniasari, F. (2017). Implementasi Pendekatan Saintifik Pada Penugasan Aktivitas Di Buku Teks Bahasa Indonesia Kelas VII SMP Berdasarkan Kurikulum 2013. Jurnal Pendidikan Edutama, 4(1), 9-26. https://doi.org/10.30734/jpe.v4i1.44

Kusumawati, N. (2016). Pengembangan Media Pembelajaran IPA Dengan Animasi Macromedia Flash Berbasis Model Pengajaran Langsung (Direct Instruction) Di Sekolah Dasar. Premiere Educandum, 5(2). https://doi.org/10.25273/pe.v5i02.289

Maarif, M., Fauziah, M., \& Fauzi, R. (2020). Effectiveness Of Direct Instruction For Learning Models Improving Batik Skills In Basic School Students In Sanggar Batik Cikadu. Jurnal Pajar (Pendidikan Dan Pengajaran), 4(1), 151-158. https://doi.org/10.33578/pjr.v4i1.7894

Mangesa, R. T., \& Andayani, D. D. (2015). Pengembangan Model Pembelajaran Berbasis Kompetensi Bidang Kelistrikan Di Sekolah Menengah Kejuruan. Jurnal Cakrawala Pendidikan, 3(3), 401-411. https://doi.org/10.21831/cp.v3i3.7356

Mulyadin. (2016). Implementasi Kebijakan Pembelajaran Tematik Terpadu Kurikulum 2013 Di SDN Kauman 1 Malang Dan SD Muhammadiyah 1 Malang. Jurnal Edutama, 3(2), 31-48. https://doi.org/10.30734/jpe.v3i2.35

Raditya, A., \& Iskandar, R. S. F. (2020). Analisis Soal PLSV pada Buku Ajar Matematika dari Kurikulum 1994 hingga Kurikulum 2013. Phenomenon: Jurnal Pendidikan MIPA, 9(2), 232-145. https://doi.org/10.21580/phen.2019.9.2.4066

Rais, A. A., \& Suswanto, H. (2017). Perbandingan Implementasi Model Problem Based Learning Dan Direct Instruction Dalam Meningkatkan Motivasi Dan Hasil Belajar Siswa Pada Mata Pelajaran Jaringan Dasar Kelas X. Jurnal Pendidikan: Teori, Penelitian, Dan Pengembangan, 2(8). https://doi.org/10.17977/jptpp.v2i8.9787

Rerung, N, Sinon, I. L. S., \& Widyaningsih, S. W. (2017). Penerapan Model Pembelajaran Problem Based Learning (Pbl) Untuk Meningkatkan Hasil Belajar Peserta Didik SMA Pada Materi Usaha Dan Energi. Jurnal Ilmiah Pendidikan Fisika Al-Biruni, 6(1), 47-55. http://ejournal.radenintan.ac.id/index.php/al-biruni/article/view/597 
Rerung, Nensy, Sinon, I. L. ., \& Widyaningsih, S. W. (2017). Penerapan Model Pembelajaran Problem Based Learning (PBL) untuk Meningkatkan Hasil Belajar Peserta Didik SMA pada Materi Usaha dan Energi. Jurnal Ilmiah Pendidikan Fisika Al-Biruni, 6(1), 47-55. https://doi.org/10.24042/jpifalbiruni.v6i1.597

Ridwan, M., \& Mas'odi, M. (2017). Tradisi Nyanyian Anak Terhadap Pembentukan Karakter Anak Usia Sekolah Dasar. Sekolah Dasar: Kajian Teori Dan Praktik Pendidikan, 26(1), 49-61. https://doi.org/10.17977/um009v26i12017p049

Risvanelli. (2017). Peningkatan Hasil Belajar dan Aktivitas Siswa Kelas V Menggunakan Pendekatan Value Clarification Technique (VCT) Pada Pembelajaran PKn di SDN 24 Batang Anai Kabupaten Padang Pariaman. JPPI Jurnal Penelitian Pendidikan Indonesia), 3(2), 44-56. https://doi.org/10.29210/02017116

Safputri, E. I., Zainuddin, Z., \& Mastuang, M. (2016). Pengembangan Perangkat Pembelajaran Fisika Pada Materi Ajar Usaha dan Energi Dengan Metode Problem Posing Dalam Setting Model Pengajaran Langsung Pada Siswa Kelas XI SMAN 4 Banjarmasin. Berkala Ilmiah Pendidikan Fisika, 4(2), 9198. https://doi.org/10.20527/bipf.v4i2.1032

Saputro, B. (2016). Manajemen Pembelajaran Direct Instruction Dalam Praktikum IPA Sebagai Kunci Keberhasilan Guru IPA Di Laboratorium. Satya Widya, 32(1), 1-10. https://doi.org/10.24246/j.sw.2016.v32.i1.p1-10

Sufanti, M., Hakim, L., \& Luckiyanti, R. (2017). Tingkat Kesulitan Dan Daya Beda Soal Tes Sumatif Bahasa Indonesia Berdasarkan Kurikulum 2013 SMP. Kajian Linguistik Dan Sastra, 26(2). https://doi.org/10.23917/kls.v26i2.4112

Surya, Y. F. (2017). Penggunaan Model Pembelajaran Pendidikan Karakter Abad 21 pada Anak Usia Dini. Jurnal Obsesi: Jurnal Pendidikan Anak Usia Dini, 1(1), 52-61. https://doi.org/10.31004/obsesi.v1i1.30

Sutrisno. (2015). Penilaian pembelajaran tematik pada kurikulum 2013 di sekolah dasar. Jurnal Sekolah Dasar, 1(1), 12-17. http://journal2.um.ac.id/index.php/sd/article/view/1356

Taunu, E. S. H., \& Iriani, A. (2019). Evaluasi Program Penguatan Pendidikan Karakter Terintegrasi Mata Pelajaran Matematika di SMP Negeri. Kelola: Jurnal Manajemen Pendidikan, 6(1), 64-73. https://doi.org/10.24246/j.jk.2019.v6.i1.p64-73

Usman, U. (2014). Penerapan Model Direct Instruction untuk Meningkatkan Kemampuan Siswa Menyusun Laporan Keuangan di SMK Negeri 1 Tarakan. Jurnal Pendidikan Humaniora, 1(3), 320-326. https://doi.org/10.17977/jph.v1i3.4141

Wahyudin, W. (2018). Optimalisasi Peran Kepala Sekolah dalam Implementasi Kurikulum 2013. Jurnal Kependidikan, 6(2), 249-265. https://doi.org/10.24090/jk.v6i2.1932

Widodo. (2014). Strategi Peningkatan Aktivitas Jasmani Siswa Sekolah Dasar di Luar Pembelajaran Pendidikan Jasmani, Olahraga, dan Kesehatan di Indonesia. Jurnal Pendidikan Dan Kebudayaan, 20(2), 281-294. https://doi.org/10.24832/jpnk.v20i2.144

Wintarti, W. (2017). Upaya Meningkatkan Prestasi Belajar IPS Melalui Model Pembelajaran DI (Direct Instruction) Dengan Media Visual Berbantuan Komputer. Premiere Educandum, 7(1), 28-38. https://doi.org/10.25273/pe.v7i01.1161

Yoserizal, \& Rahmi, U. (2019). Perbedaan Aktivitas Belajar Siswa Antara Model Cooperative Learning Tipe Snowball Throwing Dengan Tipe Think Pair Share. Jurnal Basicedu, 3(2), 1055-1064. https://doi.org/10.31004/basicedu.v3i4.247 